\title{
Potential assessment of methane and heat production from geopressured- geothermal aquifers
}

\author{
Reza Ganjdanesh* ${ }^{*}$ and Seyyed Abolfazl Hosseini
}

\author{
*Correspondence: \\ ganjdanesh@utexas.edu \\ Bureau of Economic Geology, \\ John A. and Katherine \\ G. Jackson School \\ of Geosciences, University \\ of Texas at Austin, University \\ Station, Box X, Austin, TX \\ 78713-8924, USA
}

\begin{abstract}
Geopressured-geothermal aquifers of the US Gulf Coast contain a significant amount of geothermal energy and dissolved methane. This study investigates the effect of brine reinjection on the production of heat and methane from these aquifers. First, the range of uncertainty of aquifer properties was inspected to build the reservoir model of typical aquifers. A sensitivity analysis was then performed to find favorable conditions for production with and without reinjection, and the economic criteria for both scenarios were defined. This study concludes that reinjection has several advantages, such as increasing the sustainability of production, reducing reservoir connectivity risk, and disposing of produced brine in the same formation.
\end{abstract}

\section{Background}

Formations of abnormally high pressure and temperature lie along the Gulf Coast of the United States at depths exceeding $3000 \mathrm{~m}$. The brine of these formations holds a vast amount of geothermal energy and dissolved methane. Several studies have been conducted related to the development of these geopressured-geothermal reservoirs as an energy resource for both heat recovery and natural gas (Ganjdanesh et al. 2014; Plaksina and White 2016).

During the 1970s and 1980s, the US Department of Energy (DOE) began an organized program to evaluate the production of energy from geopressured wells (Griggs 2005). The goal of the project was to provide the information necessary to assess production characteristics of geopressured-geothermal reservoirs and their economic potential. The project had two aspects: Wells of Opportunity and Design Wells (Garg et al. 1986; Klauzinski 1981; Riney 1992, 1988; Swanson et al. 1986). In the Wells of Opportunity program, several deep abandoned exploration wells in geopressured zones were recompleted and tested. In the Design Wells program, several wells were designed and drilled specifically as geopressured wells. The models in our study were built based on the results from the DOE study.

According to Jones (1976), the pressure of geopressured aquifers exceeds a pressure gradient of $10.52 \mathrm{kPa} / \mathrm{m}$. Figure 1 shows the average bottomhole shut-in pressure and temperature versus depth for several wells in Lavaca County, Texas. It is observed that the average bottomhole pressure of the wells is normal above the depth of $3000 \mathrm{~m}$ and

(c) The Author(s) 2016. This article is distributed under the terms of the Creative Commons Attribution 4.0 International License (http://creativecommons.org/licenses/by/4.0/), which permits unrestricted use, distribution, and reproduction in any medium, provided you give appropriate credit to the original author(s) and the source, provide a link to the Creative Commons license, and indicate if changes were made. 
geopressured below this depth. The temperature gradient below the depth of $3000 \mathrm{~m}$ is twice as much as one above this depth.

Estimates by different investigators of dissolved natural gas in geopressured sandstones in the Gulf of Mexico cover a wide range. The Hise (1976) estimate of the in-place natural gas was 85 trillion standard cubic meter $\left(\mathrm{sm}^{3}\right)$, while the Jones (1976) estimate was 1300 trillion $\mathrm{sm}^{3}$. Wrighton et al. (1981) estimated that the geopressured-geothermal resource of the northern Gulf of Mexico could exceed 28 trillion $\mathrm{sm}^{3}$ of recoverable natural gas. These estimates are based on different assumptions concerning the thickness of the formations, their areal extent, and the degree to which the formation is saturated with methane. These numbers are significant and several times bigger than conventional natural gas resources. However, the recovery factor was estimated to be less than 3\% (Wallace et al. 1979). (Recovery factor is defined as the produced percentage of in situ gas.)

The other available source of energy from deep saline aquifers is geothermal energy. Knapp et al. (1977) expressed that the temperature gradient in the hydrostatic pressured sediments of the Gulf Coast is about $2.7^{\circ} \mathrm{C} / 100 \mathrm{~m}$. In the geopressured zones, this gradient exceeds over $5.5^{\circ} \mathrm{C} / 100 \mathrm{~m}$. Temperature at the depth of $3000 \mathrm{~m}$ ranges from 105 to $150{ }^{\circ} \mathrm{C}$ and below $4500 \mathrm{~m}$, it exceeds $150{ }^{\circ} \mathrm{C}$.

Tertiary strata of the Texas Gulf Coast comprise a number of depositional wedges, some of which thickens abruptly at their downdip ends toward the coastline as a result of movement of growth faults and underlying rock salt. Subsidence and displacement along these faults during burial isolated thick sandstone and shale sequences. Isolation of the sandstone units prevented updip escape of pore fluids during subsequent compaction resulting from loading. Vertical escape of pore fluids was prevented by lower vertical permeability of overlying shales. Limited fluid circulation within these growth-faulted blocks caused the downward increase in pressure gradient. Furthermore, the increased porosity and water content of sediments, caused by the buildup in fluid pressure, reduce the thermal conductivity and increase the geothermal gradient. Figure 2 shows the Tertiary formations of the Gulf Coast of Texas. The prospective tertiary geopressured-geothermal formations are shown by the diagonal patterns (Bebout et al. 1978, 1982; Loucks 1978).

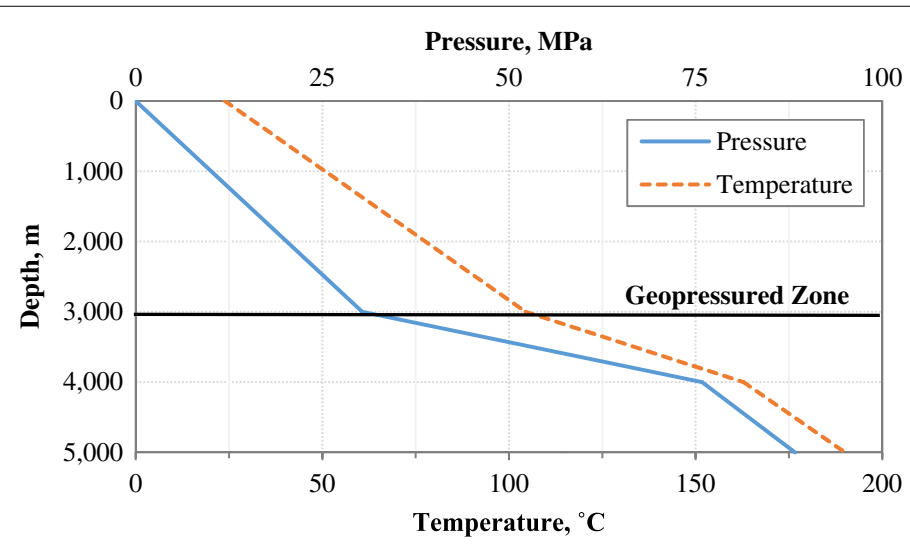

Fig. 1 Average bottomhole shut-in pressure and temperature of 57 wells in Lavaca County, Texas 
Esposito and Augustine (2011) investigated energy resources from the fairways of the Frio and Wilcox Formations of the Texas Gulf Coast using available data from the studies of the Bureau of Economic Geology (BEG) at the University of Texas at Austin (Bebout et al. 1978, 1982). Their estimate of methane-in-place for Frio and Wilcox was about 23 and 47 trillion $\mathrm{sm}^{3}$, respectively. In another study, Esposito and Augustine (2012) investigated the geopressured-geothermal formations of Texas and Louisiana. Five major geopressured-geothermal formations have been identified in Texas: lower Frio, Vicksburg-Jackson, lower Claiborne, upper Claiborne, and lower Wilcox. They concluded that the southern Vicksburg-Jackson has the highest quality geothermal resources because of thick sandstone and high temperatures.

Matthews (1981) proposed several methods for enhancing the gas production from geopressured aquifers including depletion to low pressure, pressure maintenance by reinjection of the produced brine, and formation of a gas cap by encouraging the vertical gas segregation. Ganjdanesh (2014) discussed that formation of a gas cap is not achievable because of small saturations of the liberated gas. Carbon dioxide injection into geopressured-geothermal aquifers has been introduced as a strategy to enhance energy recovery and store $\mathrm{CO}_{2}$ simultaneously. Ganjdanesh et al. (2015) proposed that $\mathrm{CO}_{2}$ can be injected in supercritical condition or co-injected with produced brine. Injected $\mathrm{CO}_{2}$ improves energy recovery by mobilizing methane (Hosseini et al. 2012), while the produced geothermal energy and methane can offset the cost of capture and storage. Recently, several studies have focused on coupled $\mathrm{CO}_{2}$ injection and brine extraction for geothermal energy recovery and enhancement of $\mathrm{CO}_{2}$ storage capacity (Hosseini and Nicot 2012; Liu et al. 2015; Salimi and Wolf 2012; Zhang et al. 2014).

Natural gas dissolved in brine has been an important energy source in Japan (Manrique and Kaneko 2000). This gas is produced from shallow aquifers formed from sandstone and siltstone, usually found at depths of $500-1000 \mathrm{~m}$. It is also estimated that water-soluble gas in geopressured-geothermal aquifers of China can be a substantial unconventional gas resource (Liu et al. 2015).

\begin{tabular}{|c|c|c|c|}
\hline Period & Sub-period & Epoch & Group or Formation \\
\hline \multirow{2}{*}{\multicolumn{2}{|c|}{ Quaternary }} & Holocene & Undifferentiated \\
\hline & & Pleistocene & Houston \\
\hline \multirow{9}{*}{ Tertiary } & \multirow{3}{*}{ Neogene } & Pliocene & Goliad \\
\hline & & \multirow{2}{*}{ Miocene } & Fleming \\
\hline & & & Anahuac \\
\hline & \multirow{6}{*}{ Paleogene } & \multirow[t]{2}{*}{ Oligocene } & Frio \\
\hline & & & Vicksburg \\
\hline & & \multirow{3}{*}{ Eocene } & lackson \\
\hline & & & Claiborne \\
\hline & & & Wilcox \\
\hline & & Paleocene & Midway \\
\hline
\end{tabular}

Fig. 2 Stratigraphic section of the tertiary and younger strata of the Texas Gulf of Mexico Coastal Plain. The prospective tertiary geopressured-geothermal formations are shown by the diagonal patterns 
This study utilized the findings of the DOE project to estimate the amount of producible energy from geopressured-geothermal aquifers of the Texas Gulf Coast. First, a simulation model of the aquifer was developed based on the Frio Formation of the Texas Gulf Coast. Then, a systematic investigation was conducted to determine the range of favorable conditions and to explore the best strategy for the coupled production of geothermal energy and natural gas. The range of conditions for sensitivity analysis was selected from the main geopressured-geothermal formations within the Texas Gulf Coast. The goal of this study is to determine whether brine reinjection is necessary for sustainable production of water and natural gas from geopressured-geothermal aquifers.

\section{Modeling parameters}

The first step of this study was to analyze the uncertainty of variables involved in the modeling of energy production from geopressured-geothermal aquifers. We investigated parameters related to reservoir size and quality, fluid properties, well productivity, and development scenarios to find out their range of variation and their effect on energy production. We used available data from the DOE program to assess the importance of the different variables.

\section{Fluid properties}

Methane content of brine depends on the initial pressure, temperature, and salinity of the brine. The range of temperatures in the geopressured zones varies from 120 to $180{ }^{\circ} \mathrm{C}$. The main geopressured-geothermal formations within Texas are lower Frio, lower and upper Claiborne, Vicksburg-Jackson, and lower Wilcox (Esposito and Augustine 2012). The temperature in all formations increases toward the coast because of the large dip of each formation. Figure 3, which illustrates formation temperatures, shows that Vicksburg-Jackson in South Texas has the highest temperature among all geopressured formations on the Texas Gulf Coast. The highest measured temperature in this formation is about $273{ }^{\circ} \mathrm{C}$ at $5000 \mathrm{~m}$.

Initial pressures in geopressured aquifers are usually more than $70 \mathrm{MPa}$. Salinity varies from 10,000 to $200,000 \mathrm{ppm}$. The solubility of methane in brine varies from 4 to $9 \mathrm{sm}^{3}$ per $\mathrm{sm}^{3}$ of brine for geopressured-geothermal conditions. Figure 4 shows the solubility of methane over wide ranges of pressure and temperature at the salinity of $105,000 \mathrm{ppm}$ (Duan and Mao 2006). Figure 5 also shows the solubility of methane over wide ranges of pressure and salinity at $150{ }^{\circ} \mathrm{C}$. Solubility of methane in brine increases by increasing pressure and temperature, and decreases by increasing salinity.

The initial condition of the reservoir fluid can be undersaturated, saturated, or oversaturated. Table 1 summarizes the initial composition and gas-water ratio for five different conditions at initial temperature, pressure, and salinity of $150{ }^{\circ} \mathrm{C}, 76 \mathrm{MPa}$ and 105,000 ppm, respectively.

Modeling the initial condition of the aquifer requires a phase-behavior model. The Peng-Robinson equation-of-state (PREOS) was used to model the interaction between methane and brine (Peng and Robinson 1976). The phase-behavior model should be tuned to the experimental data corresponding to similar pressure, temperature, and salinity conditions. Solubility of methane in brine, brine density, and the viscosity of gas 

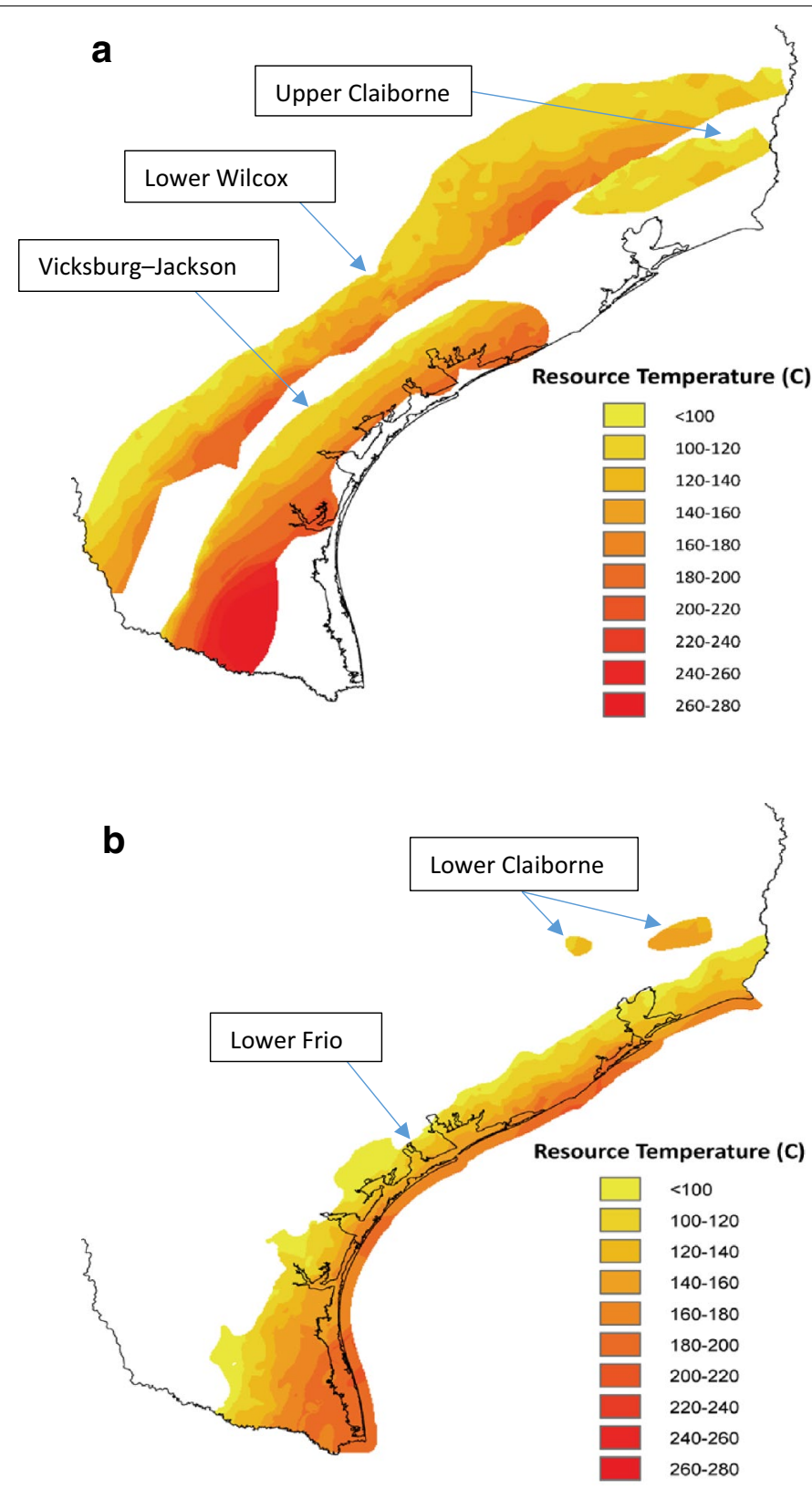

Fig. 3 Temperature of geopressured formations, Texas Gulf Coast. a Vicksburg-Jackson, lower Wilcox, upper Claiborne; b lower Frio, lower Claiborne. Esposito and Augustine (2012)

and brine are the properties that must be modeled. Binary interaction coefficients, volume shift parameters (Péneloux et al. 1982), and viscosity correlation parameters correspond to these properties. In this study, the Jossi-Stiel-Thodos correlation (Jossi et al. 1962) was used to model viscosity. This correlation could be tuned by varying the critical volume for each component. One fluid sample at the condition of $76 \mathrm{MPa}, 150{ }^{\circ} \mathrm{C}$ and $105,000 \mathrm{ppm}$ was used to build a phase-behavior model. The values of the parameters for this model are shown in Table 2 . This PREOS model accurately matches fluid properties at high pressures. A PREOS model is also needed for surface pressure and temperature 


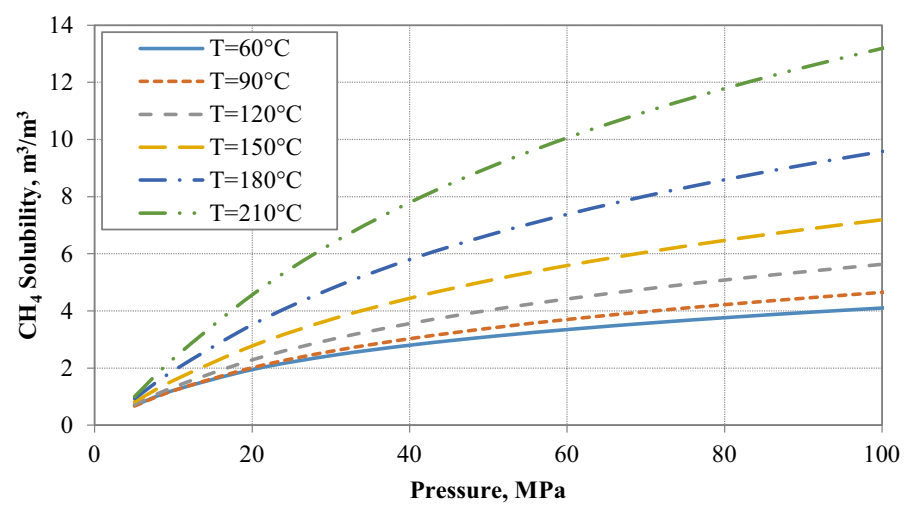

Fig. 4 Solubility of methane in brine at 105,000 ppm of $\mathrm{NaCl}$

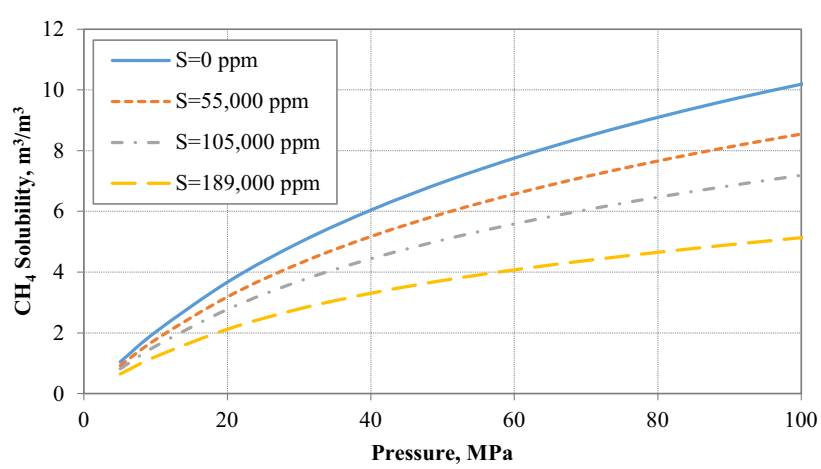

Fig. 5 Solubility of methane in brine at $150^{\circ} \mathrm{C}$

Table 1 Initial conditions of fluid at $150^{\circ} \mathrm{C}, 76 \mathrm{MPa}$, and 105,000 ppm

\begin{tabular}{lllc}
\hline Initial condition & Methane mole \% & Brine mole \% & GWR $\left(\mathbf{m}^{\mathbf{3}} / \mathbf{m}^{\mathbf{3}}\right)^{\mathbf{a}}$ \\
\hline Bubble point 33.06 MPa & 0.30 & 99.70 & 3.92 \\
Bubble point 55.56 MPa & 0.41 & 99.59 & 5.38 \\
Saturated & 0.48 & 99.52 & 6.30 \\
Gas saturation 2.5\% & 1.21 & 98.79 & 15.99 \\
Gas saturation 5.0\% & 1.96 & 98.04 & 26.09 \\
\hline
\end{tabular}

a Gas-water ratio

conditions. The solubility of methane in brine at surface conditions is negligible. Properties of gas at surface conditions are predicted accurately by ideal gas law. Volume shift is the only parameter that needs to be tuned at surface conditions. Density of the mentioned brine at aquifer conditions $\left(76 \mathrm{MPa}, 150{ }^{\circ} \mathrm{C}\right.$ and $\left.105,000 \mathrm{ppm}\right)$ is $1022.7 \mathrm{~kg} / \mathrm{m}^{3}$, while its density at surface conditions $\left(1 \mathrm{~atm}\right.$ and $\left.15.56{ }^{\circ} \mathrm{C}\right)$ is $1072.3 \mathrm{~kg} / \mathrm{m}^{3}$. This $5 \%$ difference in density emphasizes the importance of a separate phase-behavior model for surface conditions. 
Table 2 Component properties tuned for $150^{\circ} \mathrm{C}, 76 \mathrm{MPa}$, and 105,000 ppm

\begin{tabular}{lll}
\hline Component name & $\mathbf{C H}_{\mathbf{4}}$ & $\mathbf{H}_{\mathbf{2}} \mathbf{O}$ \\
\hline Critical pressure, atm & 45.4 & 217.6 \\
Critical temperature, $\mathrm{K}$ & 190.6 & 647.3 \\
Critical volume, $\mathrm{m}^{3} / \mathrm{k}$-mole & 0.099 & 0.056 \\
Molecular wt., g/g-mole & 16.043 & 19.421 \\
Acentric factor & 0.008 & 0.344 \\
Parachor & 77 & 52 \\
Omega A & 0.4572 & 0.4572 \\
Omega B & $0.077,796$ & $0.077,796$ \\
Volume shift (at reservoir conditions) & -0.15400 & 0.21591 \\
Volume shift (at surface conditions) & 0.0 & 0.15859 \\
Critical volume (viscosity), $\mathrm{m}^{3} / \mathrm{k}$-mole & 0.092217 & 0.04941 \\
Binary interaction coefficient corresponding to $\mathrm{H}_{2} \mathrm{O}$ & 0.0565 & 0 \\
\hline
\end{tabular}

Table 3 Parameters used in Corey's relative permeability function

\begin{tabular}{lc}
\hline Gas end-point relative permeability & $\mathbf{0 . 6}$ \\
\hline Water end-point relative permeability & 1.0 \\
Critical gas saturation & 0.0 \\
Connate gas saturation & 0.0 \\
Maximum trapped gas saturation & 0.345 \\
Irreducible water saturation & 0.297 \\
Gas-relative permeability exponent & 2.5 \\
Water-relative permeability exponent & 3.0
\end{tabular}

\section{Rock-fluid properties}

Flow behavior of gas at low saturation in Gulf Coast geopressured brine is a critical question. Free gas is released from brine inside the aquifer by decreasing pressure below the bubble point pressure caused by brine production. As gas bubbles continue to grow, they will eventually link up throughout the pore structure of the reservoir rock. The saturation at which this link-up occurs-critical gas saturation-depends on pore size distribution. If gas saturation builds up to a level higher than that at which a continuous gas phase is formed, gas will begin to flow. Critical gas saturation is always equal to or larger than initial gas saturation, except in gas caps (Holtz 2002; Martin 1979; Matthews 1981).

Some geopressured aquifers may initially contain some free gases, which exist when the gas saturation is below the critical gas saturation. Critical gas saturation is an important parameter in relative permeability data for production of mobile gas. It is generally assumed that critical gas saturation is about $2-5 \%$ and depends on the porosity and permeability of the reservoir rock (Matthews 1981). This study focuses only on dissolved gas or initial immobile gas; it does not examine gas caps.

Flow behavior of gas at low saturation in the presence of brine should be carefully modeled via relative permeability curves. We used a Corey-type model (Corey 1954) to build relative permeability curves for the two-phase flow of gas and brine. Table 3 summarizes the parameters used in these equations. Figure 6 illustrates the relative permeability curves of gas and liquid phases with zero critical gas saturation. This example 


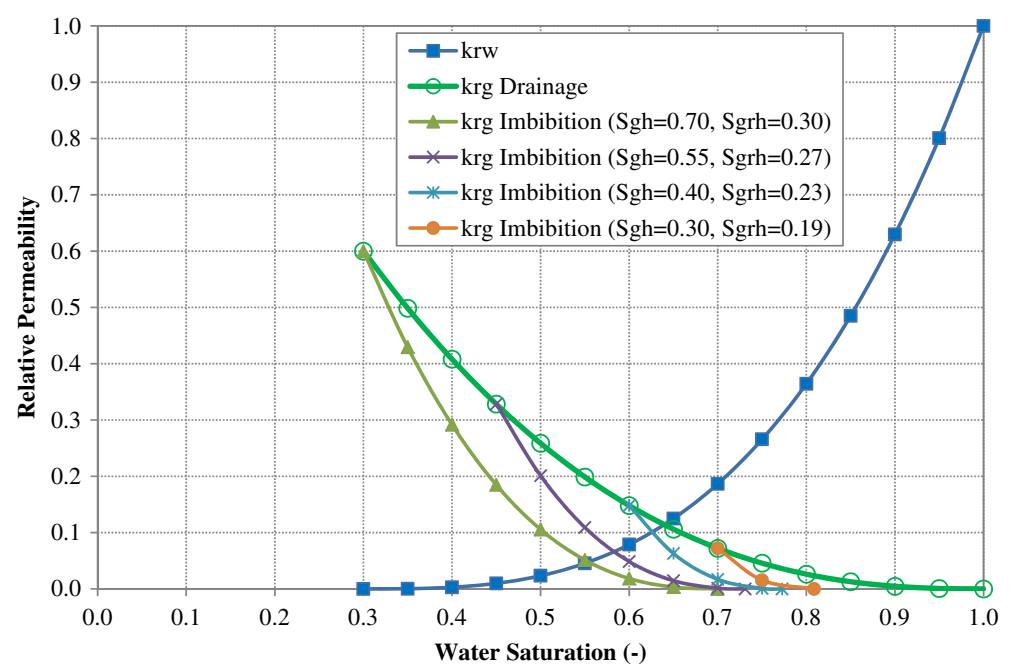

Fig. 6 Relative permeability curves with hysteresis

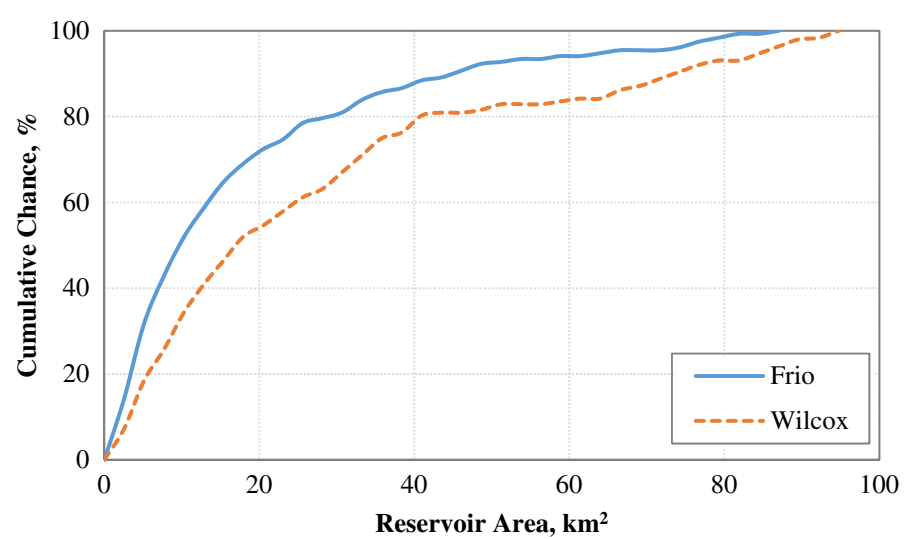

Fig. 7 Cumulative chance of areal size of fault blocks in Frio and Wilcox Formations

was built for a rock with average permeability of $20 \mathrm{mD}$. Cross-property equations introduced by Holtz (2002) were used to correlate porosity, irreducible water saturation, and maximum residual gas saturation. The corresponding porosity is 0.208 .

Since methane exsolution occurs as a result of pressure drop, a counter-current flow of gas and brine might happen in the vertical direction. Hence, hysteresis modeling for imbibition is necessary. The Holtz equation predicts that maximum trapped gas saturation is 0.345 . Figure 6 shows several gas-imbibition relative permeability curves calculated by Killough (1976) and modified Land's equation for modeling the hysteresis effect.

\section{Reservoir size}

Figure 7 shows the cumulative chance for the areal size of fault blocks in the Frio and Wilcox Formations. These plots, achieved from the data of hundreds of compartments in geopressured aquifers of Texas (Ewing 1986), show that the majority of fault blocks 
are smaller than $20 \mathrm{~km}^{2}$ and that fault blocks larger than $80 \mathrm{~km}^{2}$ can rarely be found. It is assumed that faults are sealing; thus, fault blocks are not connected to each other, and reservoir sizes and fault-block sizes are the same.

Esposito and Augustine (2012) investigated the geopressured-geothermal resource of the Gulf Coast for combined production of methane and geothermal energy, providing the areal size and average sand thickness for geopressured zones of four different formations of the Texas Gulf Coast: lower Wilcox, lower/upper Claiborne, Vicksburg-Jackson, and lower Frio. Table 4 shows the area and average sand thickness of the geopressured zone of these formations, which indicate that the lower Wilcox, lower Frio, and Vicksburg-Jackson Formations have much higher potential for energy production compared to the combined upper and lower Claiborne Formations.

\section{Quality of the reservoir sandstone}

The most important parameter indicating reservoir capability for fluid flow is permeability. Permeability of reservoir rocks in geopressured zones varies from $1 \mathrm{mD}$ for very low-quality shaly sandstone to several $100 \mathrm{mD}$ for high-quality sandstone. Many regions of geopressured aquifers contain low-permeability sandstone as a result of diagenesis caused by high temperatures. Rocks with permeability on the order of $10-20 \mathrm{mD}$ are considered to be of marginal quality (Loucks et al. 1986). Rocks with permeability higher than $20 \mathrm{mD}$ are considered to be of good quality. This sandstone quality exists only in some regions of the Frio and Wilcox Formations. The quality of sandstone at the Vicksburg-Jackson Formation is low because of very high depths and temperatures, which result in diagenesis and loss of permeability (Loucks et al. 1986).

\section{Development scenario}

We studied the process of gas evolution from high-pressure brine as pressure declines and asked questions about development scenarios, including: (1) Is it possible to drop reservoir pressure to a very low value so that huge volumes of gas evolve from the brine and flow toward the well? (2) Is it practical to perform pressure maintenance similar to conventional oil and gas reservoirs by reinjection of the produced brine?

The most important issue in the production of energy from aquifers is the necessity of reinjection of produced brine into the same aquifer, which provides pressure maintenance that leads to much higher energy recovery and resolves the issue of disposing of produced brine. The disadvantage of reinjection is the amount of required energy for pumping the reinjected brine in comparison with the amount of produced energy. Two important questions about the reinjection strategy are the rate and start time of injection.

Table 4 Area and average thickness of geopressured aquifers located at the Texas Gulf Coast

\begin{tabular}{lcccc}
\hline Formation & Lower Wilcox & Upper/lower Claiborne & Vicksburg-Jackson & Lower Frio \\
\hline Area, $\mathrm{km}^{2}$ & 42,058 & 7142 & 26,522 & 41,852 \\
Sandstone thickness, $\mathrm{m}$ & 182 & 55 & 112 & 121 \\
\hline
\end{tabular}




\section{Well productivity}

Migration of silt, clay, and sand production as a result of high production rates; precipitation of salts from solution; and evolution of free gas near the wellbore can reduce permeability near the wellbore. These effects may be estimated by including the skin factor in the models. Another important factor in well productivity is the wellbore radius. Because friction loss in the wellbore is highly dependent on wellbore radius, high production rates would correspond with high friction loss in the wellbore. A list of tubing diameters used in this study is presented in Table 5.

Several other factors affect the production of energy from geopressured-geothermal aquifers. Heterogeneity, fault-block shape, wellbore flow, salts other than $\mathrm{NaCl}$, and gases other than methane are assumed to be second-order effects with respect to the production of energy from aquifers.

\section{Simulation model}

The first step in this study was to build a base-case simulation model using the typical data for geopressured-geothermal aquifers presented in the previous section. Model dimensions are $3200 \mathrm{~m} \times 3200 \mathrm{~m} \times 120 \mathrm{~m}$. Because a five-spot well pattern is used for injection and production wells, only a quarter of the model is used in simulation as a result of symmetry. All aquifer boundaries including top, bottom, and sides are closed. Figure 8 shows a schematic of the base-case reservoir model.

The quarter of the pattern is divided into $100 \times 100 \times 40$ grid blocks. The dimension of each grid block is $16 \mathrm{~m} \times 16 \mathrm{~m} \times 3 \mathrm{~m}$. Depth at the top of the formation is

Table 5 Tubing inner and outer diameter and wellbore radius

\begin{tabular}{lll}
\hline Tubing OD (in) & Tubing ID (in) & Wellbore radius (m) \\
\hline $31 / 2$ & 2.992 & 0.03741 \\
$41 / 2$ & 3.826 & 0.04782 \\
$51 / 2$ & 4.778 & 0.05973 \\
$65 / 8$ & 6.049 & 0.07560 \\
$75 / 8$ & 7.125 & 0.08907 \\
\hline
\end{tabular}

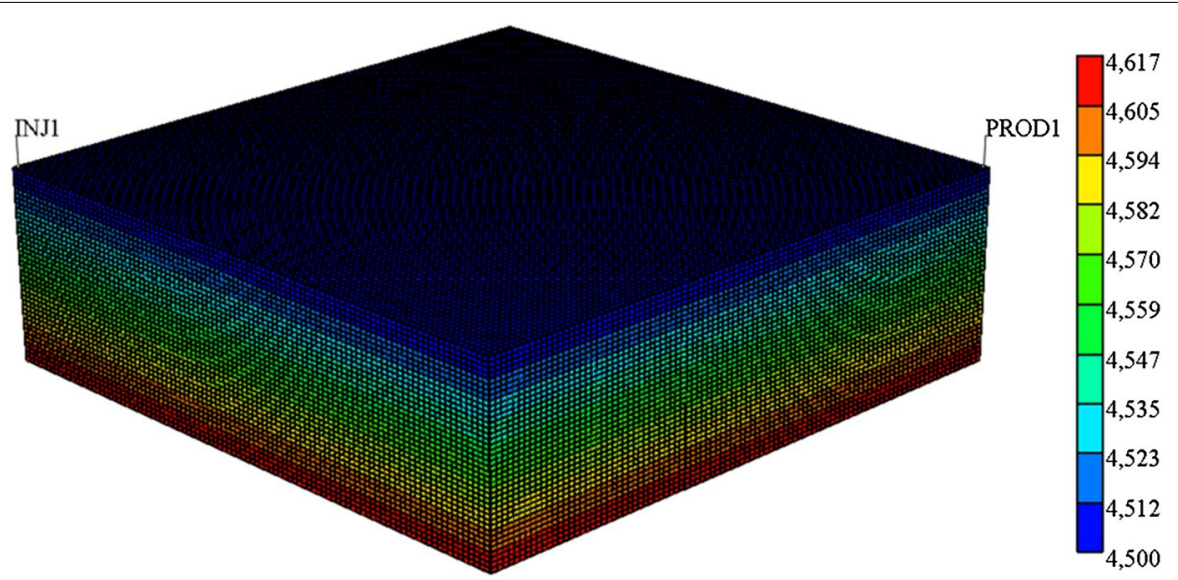

Fig. 8 3D view of a quarter of five-spot well pattern and depth $(m)$ at top of grid blocks 
Table 6 Parameters of the aquifer model in base-case study

\begin{tabular}{ll}
\hline Length and width, $\mathrm{m}$ & 1600 \\
Thickness, $\mathrm{m}$ & 120 \\
Number of grid blocks & $100 \times 100 \times 40$ \\
Grid block size, $\mathrm{m}$ & $16 \times 16 \times 3$ \\
Depth at top of formation, $\mathrm{m}$ & 4500 \\
Temperature, ${ }^{\circ} \mathrm{C}$ & 150 \\
Initial pressure, MPa & 76 \\
Salinity, ppm & 105,000 \\
Initial $\mathrm{CH}_{4}$ concentration, mole \% & 0.48063 \\
Initial brine concentration, mole \% & 99.51937 \\
Porosity, - & 0.2084 \\
Permeability, mD & 20 \\
$k_{\mathrm{v}} / \mathrm{k}_{\mathrm{h}^{\prime}}-$ & 0.1 \\
Initial $\mathrm{CH}_{4}$ in place, million $\mathrm{sm}^{3}$ & 1633.3 \\
Initial brine in place, million sm $\mathrm{sm}^{3}$ & 255.5 \\
Solution gas-water ratio, $\mathrm{m}^{3} / \mathrm{m}^{3}$ & 6.39 \\
Total pore volume, billion $\mathrm{rm}^{3}$ & 271.1 \\
\hline
\end{tabular}

$4500 \mathrm{~m}$. Initial conditions of the reservoir fluid are $76 \mathrm{MPa}, 150{ }^{\circ} \mathrm{C}$ and $105,000 \mathrm{ppm}$, similar to the conditions of the sample described in Table 2. The initial pressure gradient is $16.89 \mathrm{MPa} / \mathrm{km}$, corresponding to geopressured conditions. The brine is initially saturated with methane. Table 6 summarizes the most important properties of the aquifer model.

CMG-GEM (2015) software, a general equation-of-state compositional simulator, was used in this study. The GEM wellbore model was used to relate wellhead and bottomhole pressures, and the thermal option was used to calculate temperature variation in the aquifer as a result of injecting cold water. The wellbore radius is $0.0756 \mathrm{~m}$. The maximum liquid-production rate is $4000 \mathrm{sm}^{3} /$ day (standard cubic meter per day). It is assumed that the wellhead pressure of the producer should not drop below 1.7 MPa to keep a pressure high enough to allow fluid flow to the surface. After a period of time, wellhead pressure drops to $1.7 \mathrm{MPa}$. Then, the constraint of the maximum liquid-production rate automatically switches to minimum wellhead pressure and the production rate begins to drop until production ceases.

\section{Simulation results}

This simulation results for two development scenarios: (1) dropping reservoir pressure to a very low value so that huge volumes of gas evolve from brine and flow toward the well, and (2) performing pressure maintenance similar to that of conventional oil and gas reservoirs by reinjection of the produced brine.

\section{Scenario 1: depletion to low pressure}

For the first production scenario, the in situ fluid is produced continually from the production well until it ceases to flow because of the reservoir depletion. It is speculated that by decreasing reservoir pressure, evolved gas would form noticeable gas saturation and flow as a bulk phase toward wellbore. Critical gas saturation is selected to be zero 
for this part of the study to examine the best-case scenario for the onset of free gas flow. While it is important for economic reasons to attain a high production rate from geopressured aquifers, very high flow rates also lead to the production of small solid particles that cause erosion in tubing (Swanson et al. 1986). The maximum brine production rate is $4000 \mathrm{sm}^{3} /$ day. Table 7 shows the results of production for a 20 -year period. Figure 9 shows the brine production rate and cumulative produced brine over time.

Figure 9 shows that the reservoir can only hold the maximum production rate for less than 4 years, at which time the producer wellhead pressure drops to $1.7 \mathrm{MPa}$. The well constraint is switched to constant wellhead pressure, and the flow rate begins to drop gradually. At the end of a 20-year period, the flow rate is less than $2 \mathrm{sm}^{3}$ per day.

Figure 10 shows the gas production rate and gas-brine ratio at standard conditions. It was speculated that with pressure decline in the formation, gas would evolve from brine and be produced at a higher rate, while it was observed that gas production rate decreases with time. The gas-brine ratio decreases gradually from an initial ratio of 6.3$4.7 \mathrm{~m}^{3} / \mathrm{m}^{3}$. Preliminary results show that a fraction of in situ gas could not be produced even by decreasing pressure close to hydrostatic pressure.

Figure 11 shows the pressure profile in the top layer of the reservoir on a straight line between injector and producer for six different times. The injector is shut in throughout the whole 20 years of production. The pressure difference between the injector and the

Table 7 Simulation results for strategy 1 -depletion to low pressure

\begin{tabular}{ll}
\hline Maximum brine production rate, $\mathrm{sm}^{3} /$ day & 4000 \\
Minimum wellhead pressure of producer, MPa & 1.7 \\
Tubing ID, $\mathrm{m}$ & 0.0756 \\
Production period, year & 20 \\
Injection period, year & 0 \\
Cumulative produced brine, million sm & \\
Cumulative produced gas, million $\mathrm{sm}^{3}$ & 8.40 \\
Average produced gas-water ratio, $\mathrm{m}^{3} / \mathrm{m}^{3}$ & 46.0 \\
$\mathrm{CH}_{4}$ recovery, \% & 5.48 \\
${ }^{\text {BBine recovery, } \%}$ & 2.82 \\
\hline
\end{tabular}

a Produced percentage of in situ brine

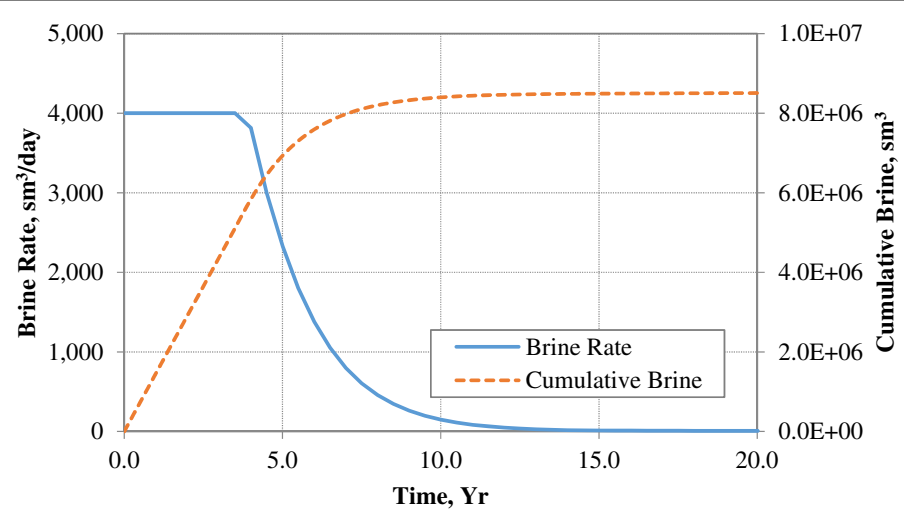

Fig. 9 Brine production rate and cumulative brine at standard conditions for depletion to low pressure 


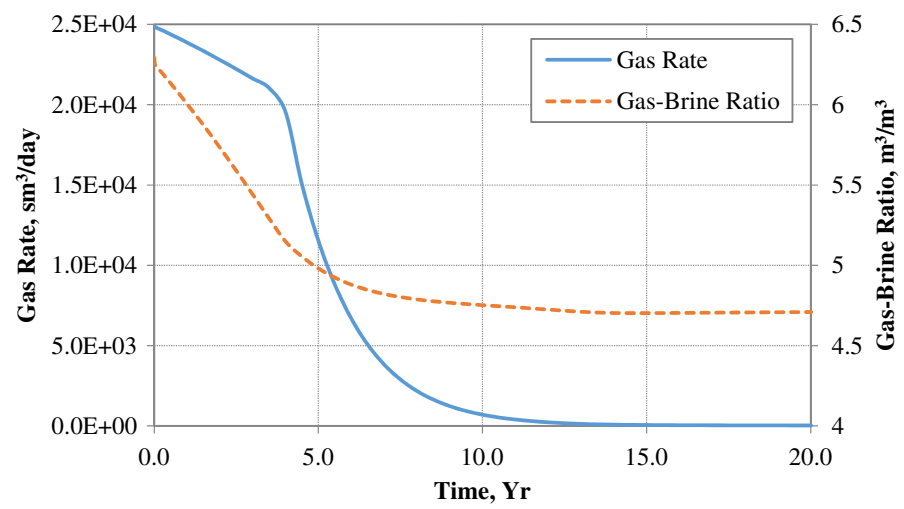

Fig. 10 Gas-production rate and gas-brine ratio at standard conditions for depletion to low pressure

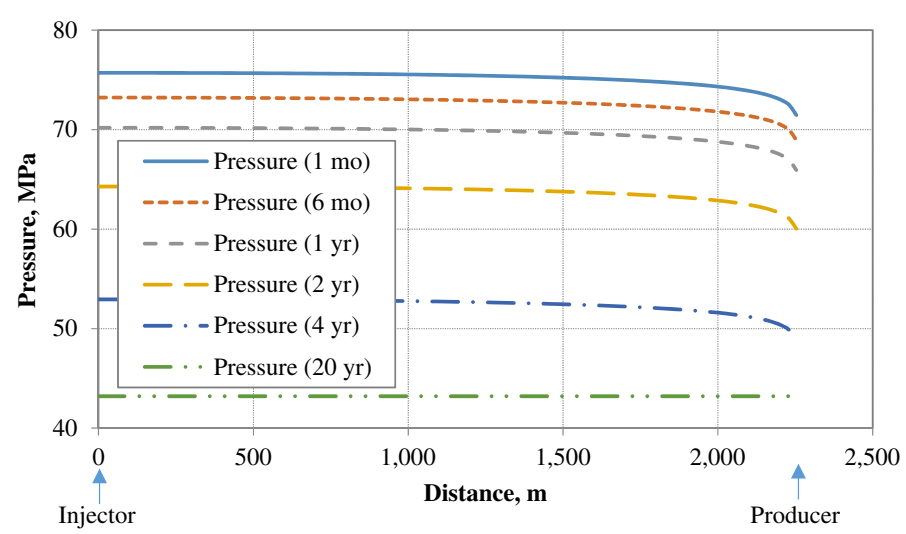

Fig. 11 Pressure profile in top layer of grid blocks between injector and producer at different times for depletion to low pressure. Injector is shut in

producer is about 3.8 $\mathrm{MPa}$ as long as the wellhead pressure of the producer is above the minimum constraint. At the end of the production period, the pressure drawdown and reservoir pressure gradient are zero. The minimum attainable pressure near the producer is about $43 \mathrm{MPa}$. Artificial lift is needed to achieve lower pressure in the aquifer. Figure 11 shows that about $1.6 \mathrm{sm}^{3}$ of methane would be released from each standard cubic meter of brine if aquifer pressure dropped from 76 to $43 \mathrm{MPa}$ (verifiable by data in Fig. 4). This is equivalent to about $0.6 \%$ gas saturation, which is not high enough to trigger significant flow of the gas phase.

Figure 12 illustrates the gas saturation profile at 20 years. The evolved gas saturation is less than $1 \%$ far from the producer and less than $2 \%$ near the wellbore. The relative permeability curve in Fig. 6 shows that the flow of gas at 2\% saturation is negligible even when assuming zero critical gas saturation. The results illuminate that the production of gas evolved by depletion of the formation is not practical without using artificial lift. Artificial lift for production of huge rates at high depths is not economically feasible (Matthews 1981). The results illuminate that only the fraction of methane dissolved in the brine near the production wellbore region can be produced along with the brine. 


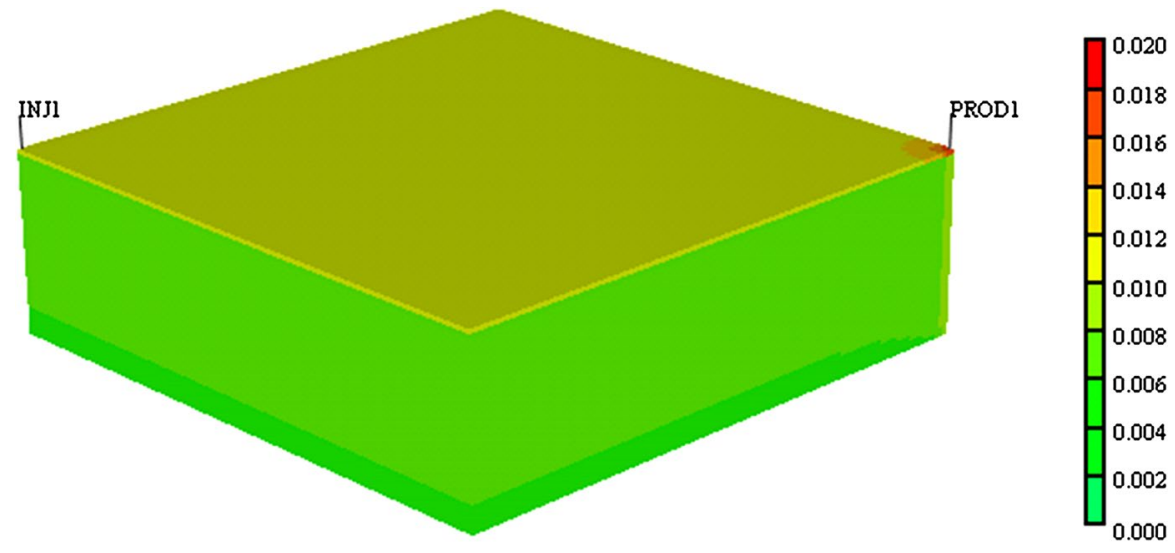

Fig. 12 Gas saturation (-) profile at 20 year (no injection)

\section{Scenario 2: pressure maintenance}

The other scenario for enhancing gas recovery from geopressured aquifers is to perform pressure maintenance, similar to that for conventional oil and gas reservoirs, by reinjection of the produced brine into the same aquifer from which it was produced. With this strategy, the aquifer first would be depleted as long as the wellhead pressure of the producer is above the minimum operating constraint and the producer maintains its maximum flow rate. As soon as the wellhead pressure of the producer reaches its minimum operating constraint, reinjection would commence at the same rate of production. The principal advantage of pressure maintenance is significant recovery of in situ methane and hot brine compared to the sole depletion. Another advantage is the disposal of extracted brine into the same formation, preventing environmental issues and land subsidence. The strategy could also make possible the exploitation of geopressured aquifers that are much smaller than those required for depletion alone. Table 8 shows the results of injection and production for a 20-year period. The base-case simulation model in "Scenario 1: depletion to low pressure" section was used in this study. It is assumed that the temperature of the produced brine is decreased to $35^{\circ} \mathrm{C}$ after passing through heat exchangers. Extracted heat can be converted into electricity using a binary cycle.

Figure 13 shows the wellhead pressure of injector and producer versus time. As soon as the wellhead pressure of the producer drops below 2.7 MPa, reinjection of the produced brine begins. After about 10 years, the wellhead pressure of injector and producer tends to be about 20.7 and $1.7 \mathrm{MPa}$, respectively.

Figure 14 shows the cumulative produced and injected brine over 20 years. After about 3.6 years, reinjection of the produced brine begins. The rate of production and reinjection is equal. There is always a difference between cumulative produced brine and injected brine, which represents the amount of produced brine before the start of reinjection. Figure 15 shows the gas production rate and produced gas-brine ratio over 20 years. The gas production rate decreases until the start of reinjection. After the beginning of reinjection, gas production remains almost constant because the pressure becomes steady by pressure maintenance. Thus, the amount of dissolved gas in brine remains constant near wellbore of production well. 
Table 8 Injection and production summary for strategy 2-pressure maintenance strategy

Maximum brine production rate, $\mathrm{sm}^{3} /$ day 4000

Minimum wellhead pressure of producer, $\mathrm{MPa}$

Minimum wellhead pressure of producer at start of reinjection, MPa

Maximum brine injection rate, $\mathrm{sm}^{3} /$ day

Maximum wellhead pressure of injector, $\mathrm{MPa}$

Temperature of reinjected brine, ${ }^{\circ} \mathrm{C}$

Tubing ID, inch

Production period, year

Injection period, year

Cumulative produced brine, million $\mathrm{sm}^{3}$

Cumulative produced gas, million $\mathrm{sm}^{3}$

Average produced gas-water ratio, $\mathrm{m}^{3} / \mathrm{m}^{3}$

Cumulative injected brine, million $\mathrm{sm}^{3}$

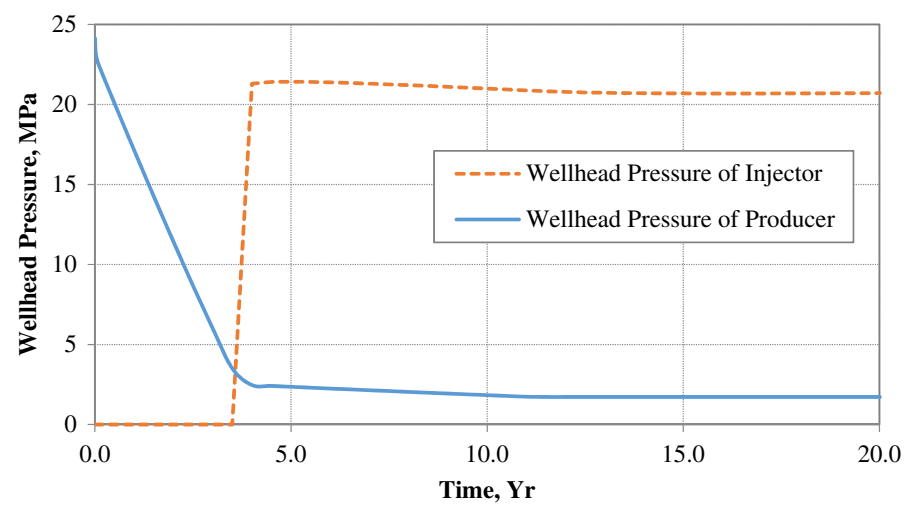

Fig. 13 Wellhead pressure of producer and injector for pressure maintenance strategy

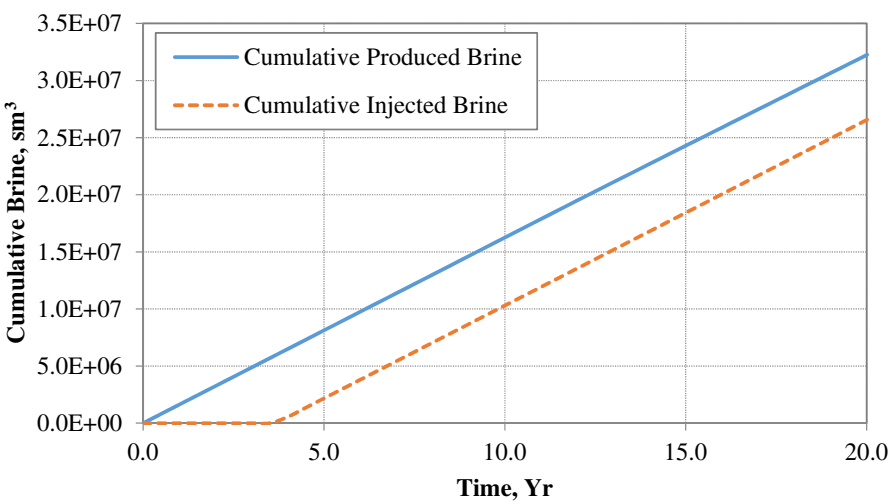

Fig. 14 Cumulative produced and injected brine for pressure maintenance strategy

Figure 16 shows the pressure profile in the top layer of the reservoir on a straight line between the injector and producer for six different times. The pressure profile becomes steady state after the start of reinjection. The pressure difference between the injector 


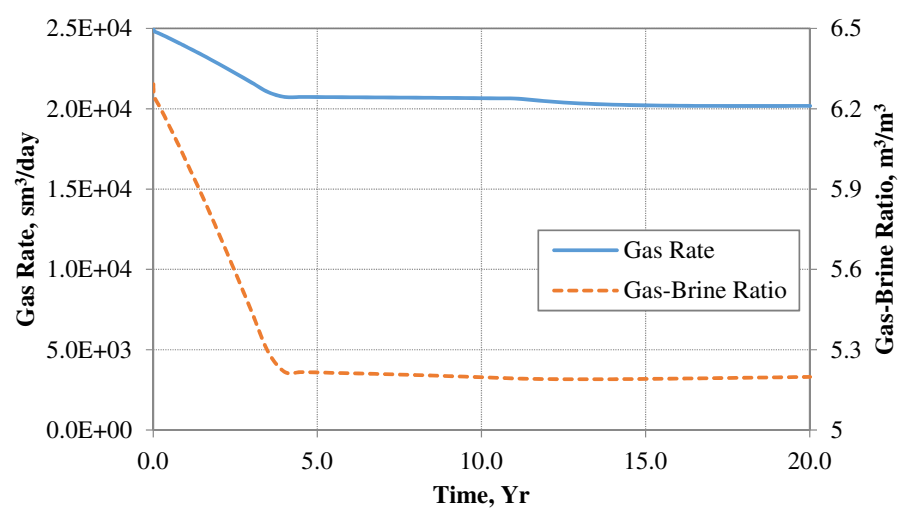

Fig. 15 Produced gas rate and gas-brine ratio for pressure maintenance strategy

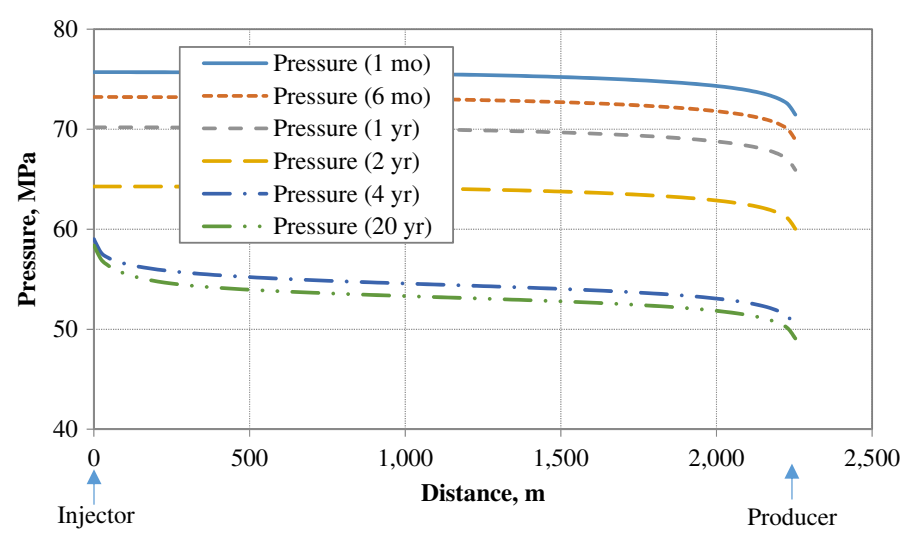

Fig. 16 Pressure profile at top layer gridblocks between injector and producer at several times for pressure maintenance strategy

and the producer is about $12.5 \mathrm{MPa}$ during this period. The released gas saturation would not go beyond $2 \%$ even close to the wellbore of the producer.

After a 20-year production of methane and brine, a significant amount of methane is still left in the aquifer. Simulation of pressure maintenance strategy continued up to 200 years, when the injected brine reached the producer. Figures 17 and 18 illustrate the $\mathrm{CH}_{4}$ mol fraction distribution and temperature distribution after 200 years. The zero- $\mathrm{CH}_{4}$ concentration in Fig. 17 corresponds to the region swept by injected brine. Comparing the front of injected brine in Fig. 17 and the front of temperature in Fig. 18 specifies that the temperature front falls behind the mass front. The temperature of the produced brine remains constant several years after sweeping almost all of the methane. Therefore, geothermal energy production can be continued even after the breakthrough of methane-free brine.

Scaling is one of the problems caused by temperature and pressure drop in aquifer, wellbore, and surface facilities (Abouie 2015). A decline in injectivity as a result of precipitation in the formation and clogging of the wellbore and surface facilities is considered a key technical and economic issue. Several water treatment techniques and inhibitors have been developed to help control the chemical balance and prevent scale precipitation (Crabtree et al. 1999). 


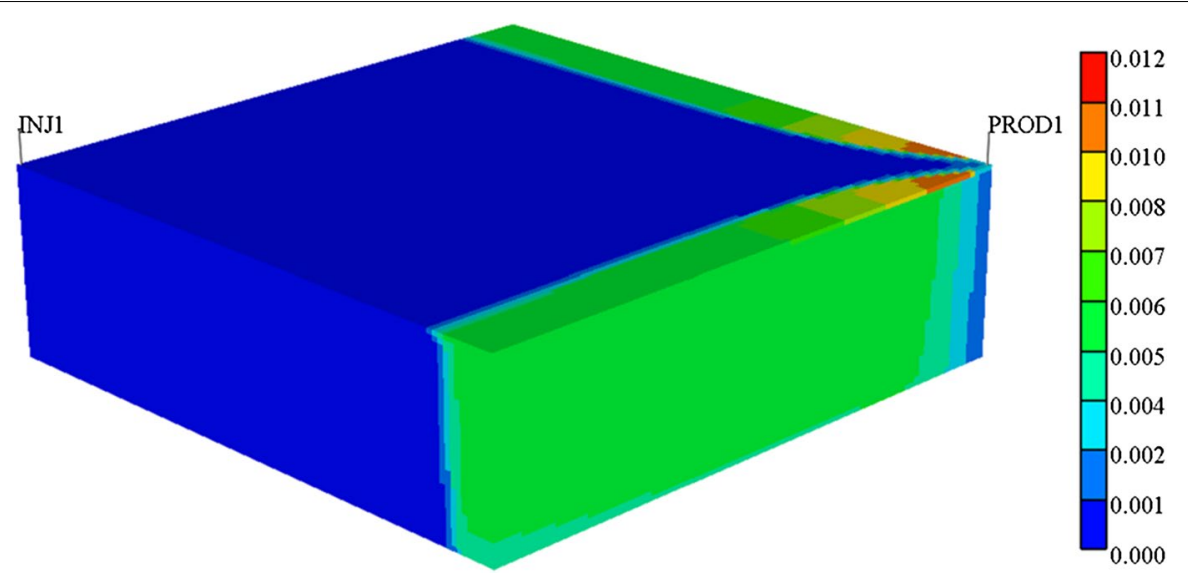

Fig. 17 Distribution of $\mathrm{CH}_{4}$ concentration (-) after 200 year (reinjection)

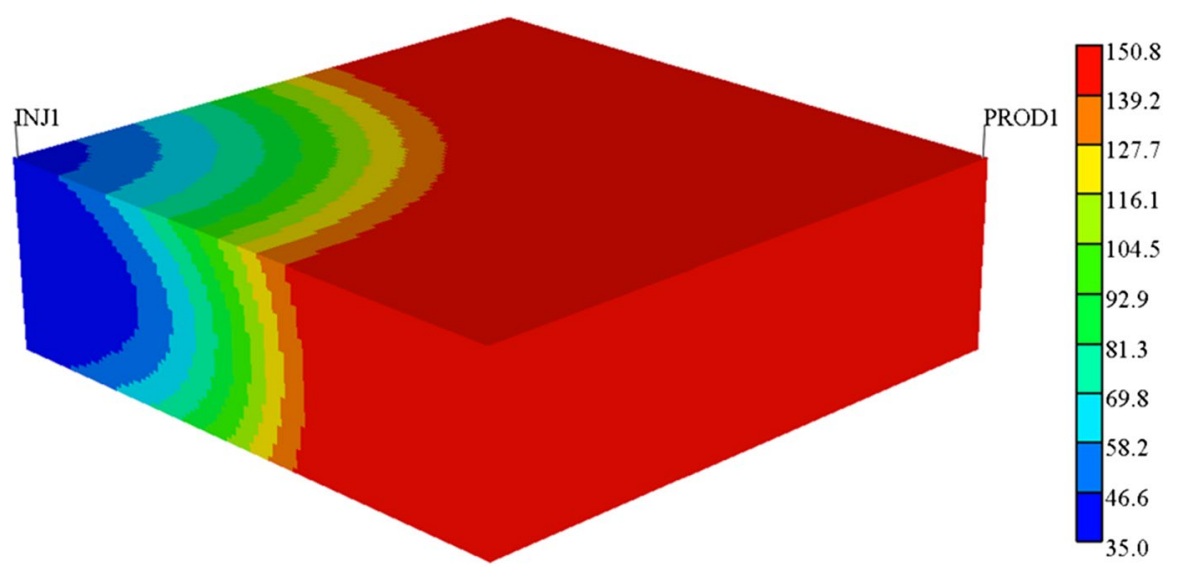

Fig. 18 Distribution of temperature $\left({ }^{\circ} \mathrm{C}\right)$ after 200 year (reinjection)

\section{Comparison of strategies}

Results show that the pressure maintenance strategy has the advantage of keeping brine and gas production rates constant during the 20-year period. Hence, the energy recovery factor is much higher compared to that of the depletion case. Also, the recovery factor is almost $10 \%$, indicating the presence of significant amounts of energy still in place at the end of the 20-year period. Thus, we conclude that the pressure maintenance scenario requires a much smaller aquifer size compared to that of the aquifer depletion case.

Table 9 summarizes energy produced from methane and geothermal energy, as well as the energy required for reinjection or disposal of the produced brine for both strategies. The gross energy from methane is calculated based on the lower heating value of methane. The efficiency of converting the heating value of methane to work is assumed to be $45 \%$. The gross heat from hot brine is extracted by decreasing the brine temperature in a heat exchanger. The extracted heat can be transferred to the working fluid of a binary Organic Rankine Cycle (ORC) to generate work. The thermal efficiency of this cycle is about 12 percent for inlet and outlet temperatures of 150 and $35^{\circ} \mathrm{C}$, respectively (MIT 
Table 9 Energy balance analysis for both production strategies

\begin{tabular}{lll}
\hline & Disposal (no injection) & Reinjection \\
\hline Net methane work (Joule) & $+0.793 \mathrm{E}+15$ & $+2.635 \mathrm{E}+15$ \\
Net geothermal work (Joule) & $+0.468 \mathrm{E}+15$ & $+1.604 \mathrm{E}+15$ \\
Pump work (Joule) & $-0.036 \mathrm{E}+15$ & $-0.637 \mathrm{E}+15$ \\
Net generated work (Joule) & $+1.225 \mathrm{E}+15$ & $+3.602 \mathrm{E}+15$ \\
Average net power in 20 year (MW) & +1.942 & +5.711 \\
\hline
\end{tabular}

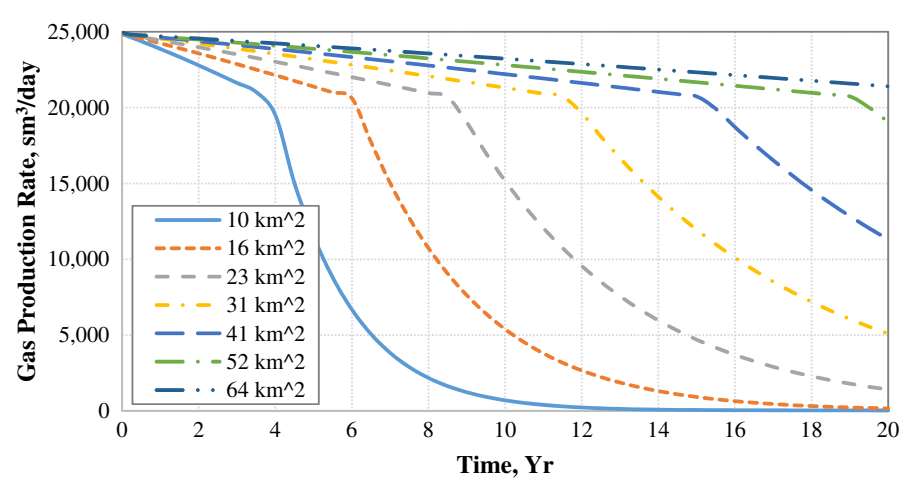

Fig. 19 Sensitivity of gas production rate to drainage area without reinjection

2006). The work required to pump up the brine to wellhead pressure is calculated using the mechanical energy balance equation,

$$
W_{\text {brine }}=\frac{V_{\text {brine }}\left(P_{\text {wellhead }}-P_{\mathrm{i}}\right)}{\eta_{\text {pump }}}
$$

where $V_{\text {brine }}$ is the volume of injected brine, the pump inlet pressure $\left(P_{\mathrm{i}}\right)$ is $0.1 \mathrm{MPa}$, and the pump efficiency $\left(\eta_{\text {pump }}\right)$ is $80 \%$. The average wellhead pressure for reinjection into the same aquifer is about $20.7 \mathrm{MPa}$, while the wellhead pressure for disposal into a shallow aquifer is assumed to be $3.5 \mathrm{MPa}$.

Results of energy calculations in Table 9 show that the pump work for reinjecting produced brine into the same aquifer is much higher compared to the pump work for disposal into a shallow aquifer. However, the net generated work from the reinjection strategy is also much higher, about three times larger than the net generated work from the no-injection strategy.

Figures 19 and 20 show the sensitivity of gas production rate versus drainage area of the producer for the no-injection and reinjection strategies. All other properties of the aquifer are the same as in the base-case model summarized in Table 6. Figure 19 shows that the drainage area of the producer should be more than $50 \mathrm{~km}^{2}$ to maintain a constant production rate over 20 years without reinjection, while the drainage area can be as low as $1 \mathrm{~km}^{2}$ to maintain a constant production rate with reinjection. It is observed that the drainage area should be about two orders of magnitude larger to keep the production rate constant without reinjection for 20 years. 


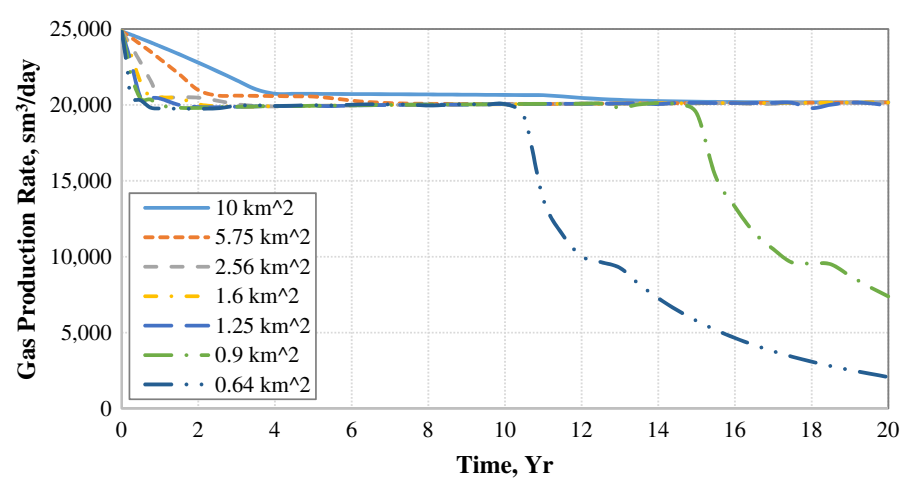

Fig. 20 Sensitivity of gas production rate to drainage area with reinjection

The decline curves of the two production strategies exhibit different characteristics. The main production mechanisms of the no-injection case are fluid and rock expansion, while the main production mechanism of the reinjection case is pressure maintenance. Therefore, a much larger drainage area is needed for the no-injection scenario to keep the production rate constant over a 20 -year production period.

\section{Sensitivity analysis}

Parameter space sampling is the most important step in sensitivity analysis and uncertainty assessment. The outcome of parameter space sampling is a design for laying out a detailed simulation plan in advance of doing simulations. A well-selected design maximizes the amount of information that can be obtained for a given amount of simulation effort. Figure 21 shows an uncertainty prioritization matrix. Parameters are prioritized based on their expected impact on results and the ability to include them in the study based on computational cost.

Table 10 summarizes all the six parameters and their samples involved in the sensitivity analysis. Five samples are selected for each parameter based on the information from

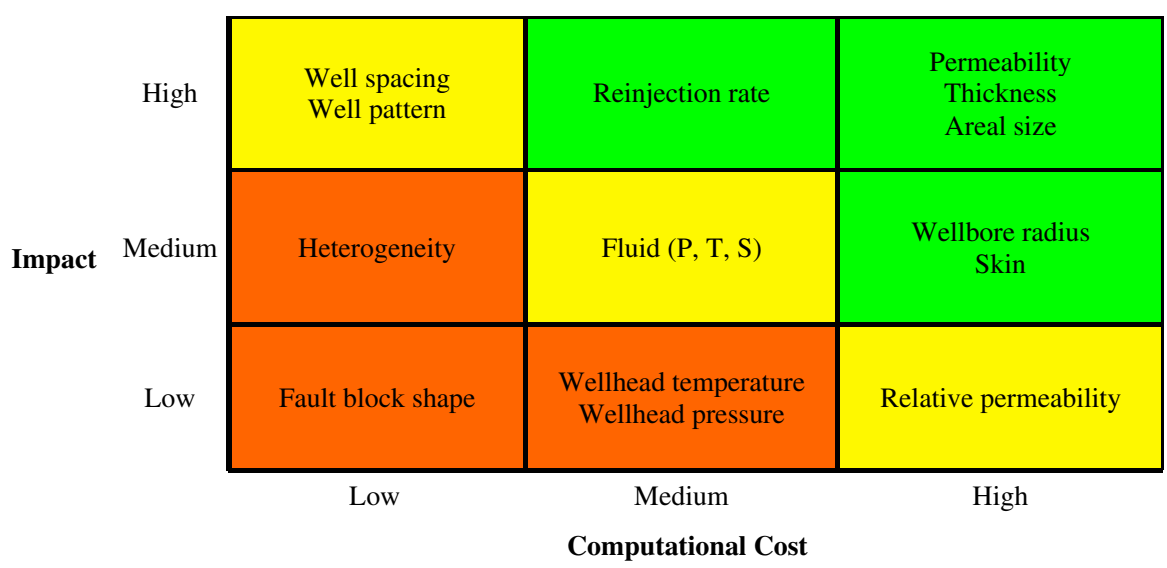

Fig. 21 Uncertainty prioritization matrix. The green blocks contain the parameters with the highest priority for sensitivity analysis. The red blocks contain the parameters with the lowest priority for sensitivity analysis 
Table 10 Samples of parameters in sensitivity analysis

\begin{tabular}{lccccc}
\hline Parameters & Samples & & & \\
\hline${\text { Size, } \mathrm{mi}^{2}}^{\text {Thickness, } \mathrm{ft}}$ & 2.56 & 10 & 23 & 41 & 64 \\
Permeability, md $_{\text {Reinjection ratio, \% }}$ & 54 & 90 & 120 & 150 & 180 \\
Skin factor, - & 2 & 10 & 20 & 50 & 100 \\
Tubing ID, $\mathrm{m}$ & 0 & 25 & 50 & 75 & 100 \\
\hline
\end{tabular}

the uncertainty analysis. Therefore, the parameter space, which is the number of all possible job patterns, is 15,625 .

It is not feasible to perform simulations over the whole parameter space. Therefore, a sampling method is used to select a subset of the whole parameter space. A set of job patterns generated by sampling method is called a design. A good design with favorable characteristics can be used to fit an accurate proxy model and draw reliable conclusions regarding parameter effects. The collection of job patterns (computational experiments) should be a representative subset of all possible job patterns.

In this study, first the "one-parameter-at-a-time" method is used to draw preliminary conclusions, which help to shrink the parameter space significantly. In this method, one of the parameters is varied over the range of samples, and all other parameters are fixed at a base-case condition. This procedure was performed for all parameters. The strategy of brine reinjection for pressure maintenance was selected for the base-case model. It is assumed that the maximum brine production rate is $4000 \mathrm{sm}^{3} /$ day and that the wellhead pressure of the injector is limited to $31 \mathrm{MPa}$. Cumulative produced brine and cumulative produced gas were chosen as objective functions.

Tornado plots are a visual display of the effect of variation of parameters on objective functions. There is one tornado plot for each objective function. Based on their impacts on the objective functions, parameters or terms are ordered in the sequence from the most to the least important. Figure 22 shows the tornado chart for cumulative produced brine. Based on the results of the "one-parameter-at-a-time" method, we have drawn the following preliminary conclusions:

- The largest increase in water production occurs when permeability increases from 2 to $10 \mathrm{mD}$. The production is not sensitive to permeability above $20 \mathrm{mD}$. Permeabilities less than $10 \mathrm{mD}$ are considered as poor quality. Permeabilities between 10 and $20 \mathrm{mD}$ are considered as marginal quality. Permeabilities higher than $20 \mathrm{mD}$ are considered as good quality.

- The relationship between the change in skin effect of wellbore and the change in production is almost linear.

- When decreasing the tubing ID below $0.1214 \mathrm{~m}$, a significant drop in production rate occurred. 


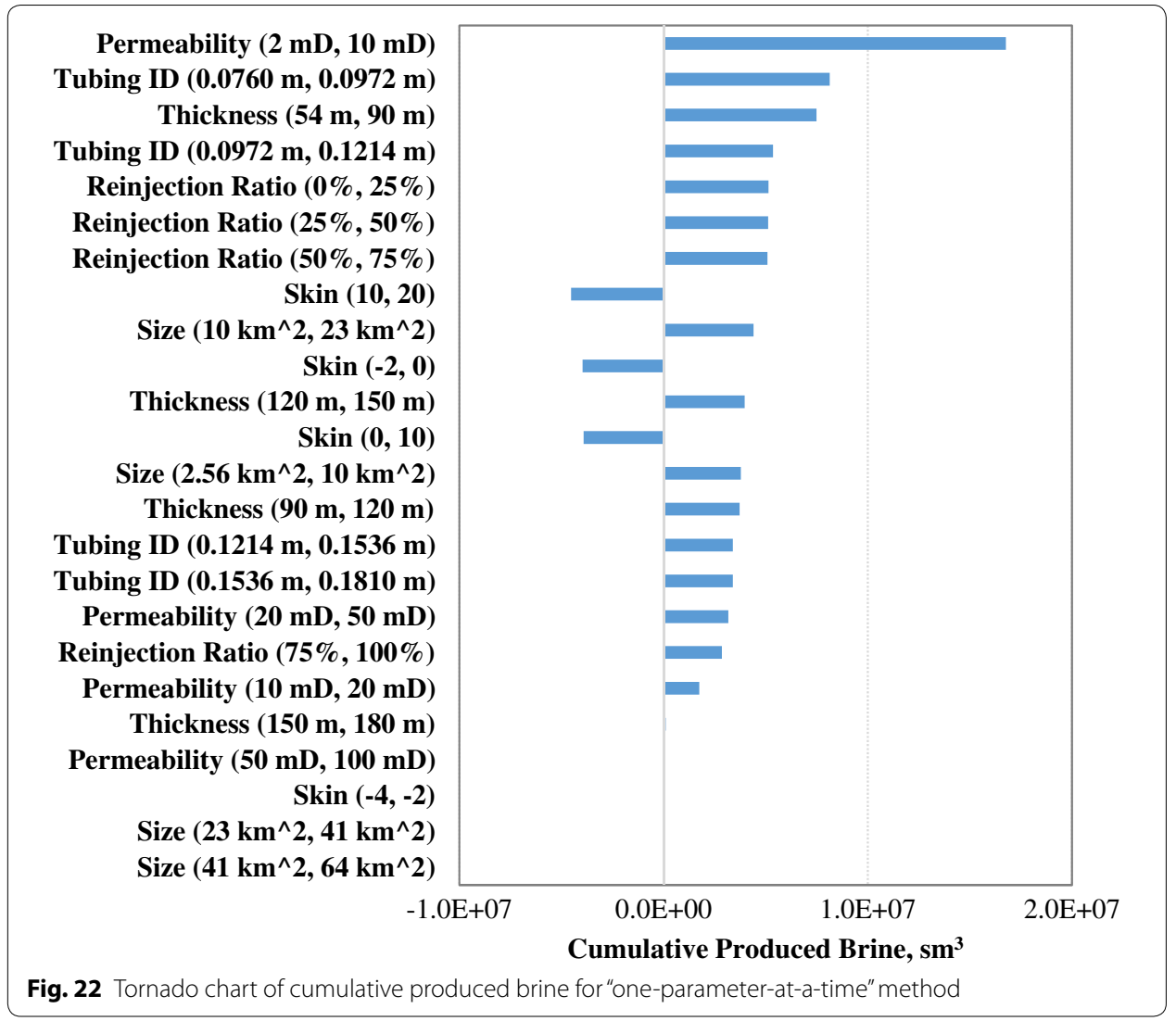

\section{Economic criteria}

A sensitivity analysis on important formation properties was performed to determine the economic criteria for both no-injection and reinjection cases. These two cases are identical to depletion to low pressure and pressure maintenance, respectively. Since the behavior of the results is very different for reinjection and no-injection cases, it is necessary to do separate sensitivity analysis for these cases. Size, thickness, and permeability are chosen as formation parameters, with five samples for each parameter. The parameter space is 125; 50 samples are selected using the Latin hypercube method. The same samples are used for both reinjection and no-injection cases. Figure 23 shows the tornado chart for the case of no injection for cumulative produced water and gas. It can be concluded from the tornado chart that reservoir size is the dominant parameter affecting the production of brine and natural gas, while the impacts of reservoir thickness and permeability are minor, because expansion is the main mechanism. Thus, larger aquifers perform better. Figure 24 shows the water production rate after 20 years for all 50 cases versus the volume of the aquifer. Considering a maximum $6 \%$ decline in production rate per year as a criterion for the case of no injection, the economic criterion after 20 years would be a production rate of $1200 \mathrm{sm}^{3} /$ day. Figure 24 shows that regardless of the reservoir permeability, the volume of the aquifer should be at least $4.0 \mathrm{~km}^{3}$ to have this minimum production rate after 20 years.

Figure 25 shows the tornado chart for the case of reinjection for cumulative produced water and gas. It can be seen from the chart that permeability and thickness have the 


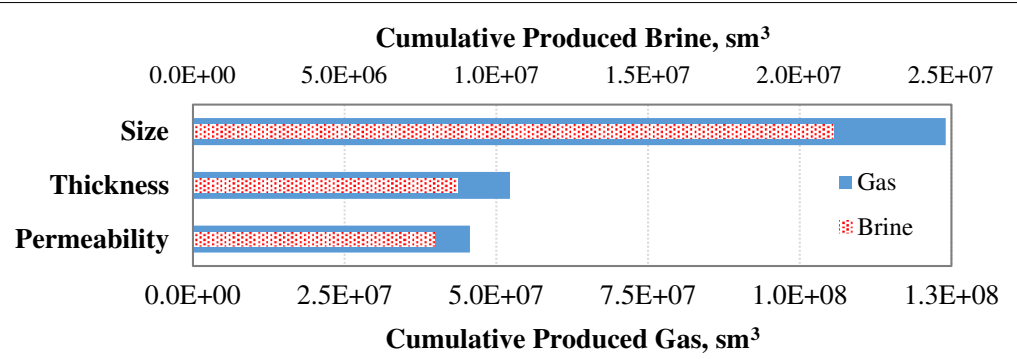

Fig. 23 Tornado chart for cumulative gas and brine (no injection)

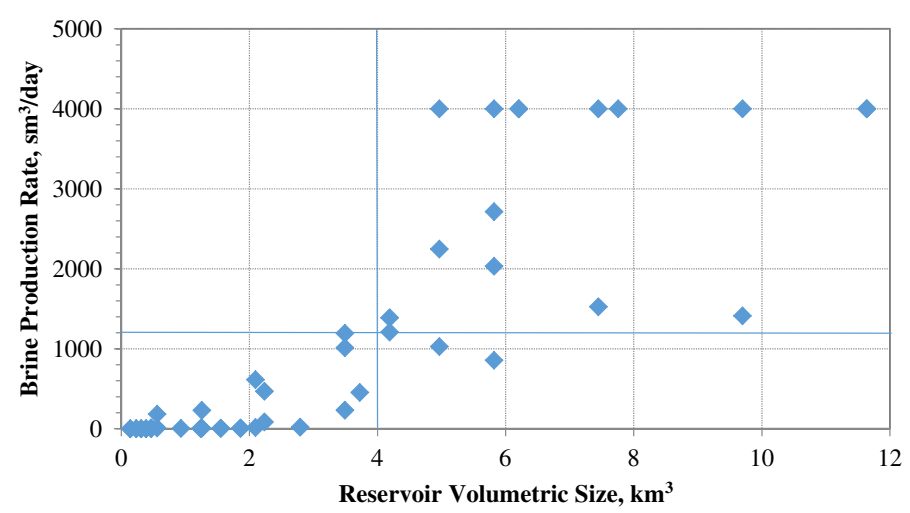

Fig. 24 Brine production rates after 20 year versus aquifer volume for 50 job patterns for areal size, thickness, and permeability (no injection). The horizontal blue line distinguishes the cases which have a brine production rate higher than $1200 \mathrm{sm}^{3} /$ day after 20 years. The vertical blue line distinguishes the cases which have a volume of at least $4 \mathrm{~km}^{3}$

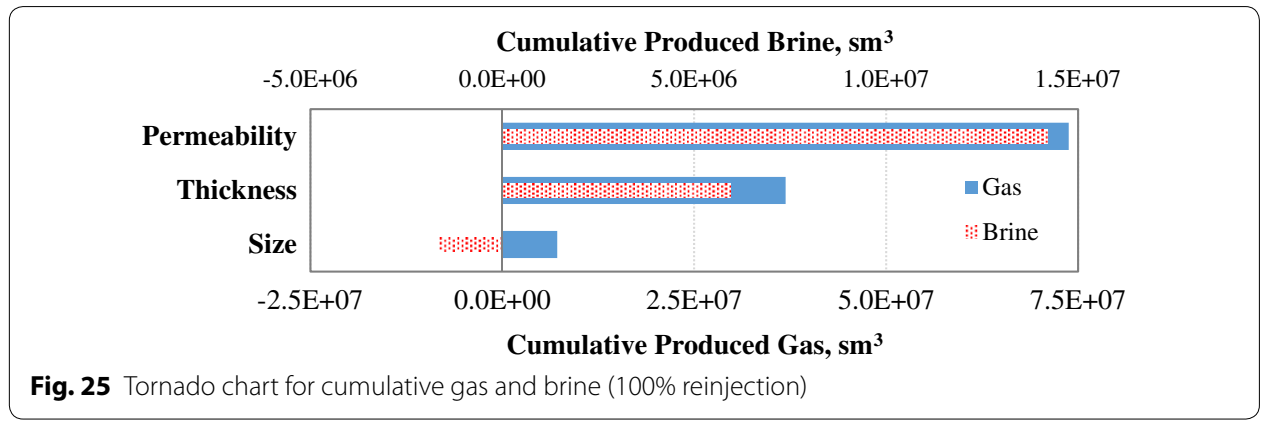

dominant effects on production; the effect of size is negligible because pressure maintenance is the main production mechanism. Figure 26 shows the relationship between the brine production rate after 20 years and the product of the reservoir permeability and thickness for all 50 cases in the strategy of brine reinjection. Considering a maximum $10 \%$ decline in production rate over the whole 20 years for the case of reinjection, the economic criterion after 20 years would be a production rate of $3600 \mathrm{sm}^{3} /$ day. Figure 26 shows that the product of the reservoir permeability and thickness of the aquifer should be at least $1500 \mathrm{mD} \times \mathrm{m}$ to have this minimum production rate after 20 years. The majority of the cases maintain a very high production rate after 20 years. 


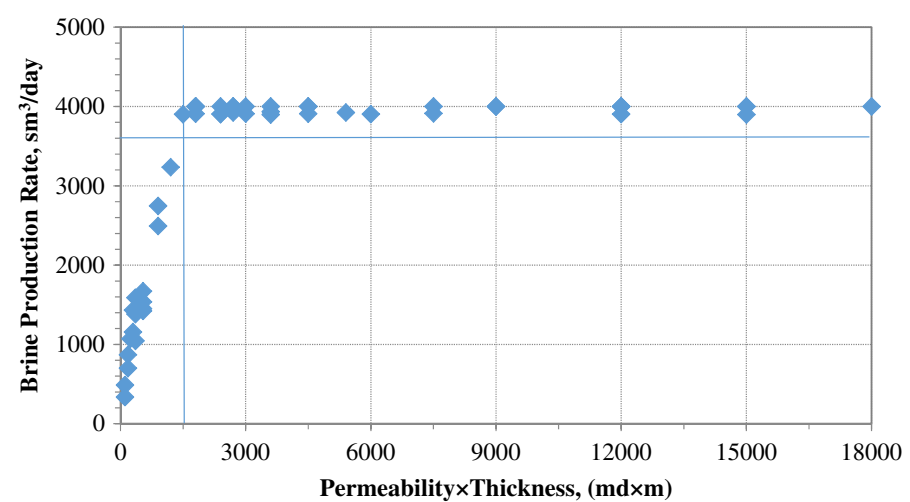

Fig. 26 Brine production rates after 20 year for 50 job patterns for areal size, thickness, and permeability (100\% reinjection). The horizontal blue line distinguishes the cases which have a brine production rate higher than $3600 \mathrm{sm}^{3} /$ day after 20 years. The vertical blue line distinguishes the cases which have a permeability $\times$ thickness of at least $1500 \mathrm{mD} \times \mathrm{m}$

\section{Summary and conclusions}

This study examines the feasibility of energy production from geopressured-geothermal aquifers of the US Gulf Coast. Uncertainty of parameters was studied from available data. Results of reservoir simulations were presented for various production scenarios. Finally, sensitivity analysis was performed to determine the effect of aquifer properties on produced energy and to define economic criteria. The conclusions of this study are as follows:

- Reservoir volume is the governing factor in production by depletion. A very small percentage of immobile gas can be produced by reservoir depletion. Production of gas evolved by depletion of the formation is not practical without using artificial lift. Artificial lift for production of huge rates at high depths is not economically feasible.

- The product of thickness and permeability $(k \times h)$ is the governing factor in production by reinjection. Pressure maintenance has the advantage of keeping brine and gas production rates constant during the 20 -year period. The pressure maintenance scenario requires a much smaller aquifer size compared to that of the depletion case. The energy recovery factor for the pressure maintenance case is much higher compared to that of the depletion case. Reinjection has several advantages, such as increasing the sustainability of production, disposal of produced brine in the same formation, and better energy balance.

Authors' contributions

Both authors contributed to discussions according to their respective areas of expertise and experience to the interpretation of data and development of the basic concepts and assumptions which constitute the reservoir model. RG set up the numerical model, conducted and interpreted numerical simulations, and drafted the manuscript. SAH contributed to the geological model, numerical simulations, and drafting of the manuscript. Both authors read and approved the final manuscript.

Acknowledgements

We would like to thank CMG for the educational license of their software that was used in this study.

\section{Competing interests}

The authors declare that they have no competing interests. 


\section{References}

Abouie A. Development and application of a compositional wellbore simulator for modeling flow assurance issues and optimization of field production (Thesis). Austin: The University of Texas at Austin; 2015.

Bebout DG, Loucks R, Gregory AR. Frio sandstone reservoirs in the deep subsurface along the Texas Gulf Coast: their potential for production of geopressured geothermal energy (No. Report of Investigations No. 91). Austin: Bureau of Economic Geology, The University of Texas at Austin; 1978.

Bebout DG, Weise BR, Gregory AR, Edwards MB. Wilcox sandstone reservoirs in the deep subsurface along the Texas Gulf Coast: their potential for production of geopressured geothermal energy (No. Report of Investigations No. 117). Austin: Bureau of Economic Geology, The University of Texas at Austin; 1982.

Corey AT. The interrelation between oil, gas relative permeabilities. Prod Mon. 1954;19:38-41.

Crabtree M, Eslinger D, Fletcher P, Miller M, Johnson A, King G. Fighting scale-removal and prevention. Oilfield Rev. 1999;11:30-45.

Duan Z, Mao S. A thermodynamic model for calculating methane solubility, density and gas phase composition of methane-bearing aqueous fluids from 273 to $523 \mathrm{~K}$ and from 1 to 2000 bar. Geochim Cosmochim Acta. 2006;70:3369-86. doi:10.1016/j.gca.2006.03.018.

Esposito A, Augustine C. Recoverable resource estimate of identified onshore geopressured geothermal energy in Texas and Louisiana (Presentation). Golden: National Renewable Energy Laboratory (NREL); 2012.

Esposito A, Augustine C. Geopressured geothermal resource and recoverable energy estimate for the Wilcox and Frio Formations, Texas. GRC Trans. 2011;3:1563-71.

Ewing TE. Structural styles of the Wilcox and Frio growth-fault trends in Texas: constraints on geopressured reservoirs (No. Report of Investigations No. 154). Austin: Bureau of Economic Geology, The University of Texas at Austin; 1986.

Ganjdanesh R. Integrating carbon capture and storage with energy production from saline aquifers. Dissertation, The University of Texas at Austin. 2014.

Ganjdanesh R, Bryant S, Orbach R, Pope G, Sepehrnoori K. Coupled carbon dioxide sequestration and energy production from geopressured/geothermal aquifers. SPE J. 2014;19:239-48. doi:10.2118/163141-PA.

Ganjdanesh R, Pope GA, Sepehrnoori K. Production of energy from saline aquifers: a method to offset the energy cost of carbon capture and storage. Int J Greenh Gas Control. 2015;34:97-105. doi:10.1016/j.ijggc.2015.01.004.

Garg SK, Riney TD, Wallace RH. Brine and gas recovery from geopressured systems. Geothermics. 1986;15:23-48. doi:10.1016/0375-6505(86)90027-1.

Computer Modeling Group (CMG). GEM technical manual. Computer Modeling Group (CMG): Calgary; 2015.

Griggs J. A re-evaluation of geopressured-geothermal aquifers as an energy resource. In: Proc. 30th workshop on geothermal reservoir engineering, Stanford University; 2005.

Hise BR. Natural gas from geopressured zone. In: Nat Gas Unconv Geol Sources. 1976

Holtz MH. Residual gas saturation to aquifer influx: a calculation method for 3-D computer reservoir model construction. In: Presented at the SPE Gas Technology symposium, Society of Petroleum Engineers, Calgary; 2002. doi:10.2118/75502-MS.

Hosseini SA, Mathias SA, Javadpour F. Analytical model for $\mathrm{CO}_{2}$ injection into brine aquifers-containing residual $\mathrm{CH}_{4}$. Transp Porous Media. 2012;94:795-815. doi:10.1007/s11242-012-0025-x.

Hosseini SA, Nicot J-P. Scoping analysis of brine extraction/re-injection for enhanced $\mathrm{CO}_{2}$ storage. Greenh Gases Sci Technol. 2012;2:172-84. doi:10.1002/ghg.1283.

Jones PH. Natural gas resources of the geopressured zones in the northern Gulf of Mexico basin. In: Nat Gas Unconv Geol Sources. Washington: National Academy of Sciences; 1976. p. 17-31.

Jossi JA, Stiel LI, Thodos G. The viscosity of pure substances in the dense gaseous and liquid phases. AlChE J. 1962;8:5963. doi:10.1002/aic.690080116

Killough JE. Reservoir simulation with history-dependent saturation functions. Soc Pet Eng J. 1976;16:37-48. doi:10.2118/5106-PA.

Klauzinski RZ. Testing of six wells of opportunity during 1980 and 1981 (No. DOE/ET/27081-6-Rev; CONF-811026-1). Houston: Eaton Operating Co., Inc.; 1981.

Knapp RM, Isokrari OF, Garg SK, Pritchett JW. An analysis of production from geopressured geothermal aquifers. In: Presented at the SPE annual fall technical conference and exhibition, Society of Petroleum Engineers, Denver; 1977. doi:10.2118/6825-MS.

Liu H, Hou Z, Were P, Sun X, Gou Y. Numerical studies on $\mathrm{CO}_{2}$ injection-brine extraction process in a low-medium temperature reservoir system. Environ Earth Sci. 2015;73:6839-54. doi:10.1007/s12665-015-4086-3.

Loucks RG. Geothermal resources, Vicksburg Formation, Texas Gulf Coast (No. ORO-4891-2). Austin: Bureau of Economic Geology, Texas Univ; 1978

Loucks RG, Dodge MM, Galloway WE. Controls on porosity and permeability of hydrocarbon reservoirs in Lower Tertiary sandstones along the Texas Gulf Coast (No. Report of Investigations No. 149). Austin: Bureau of Economic Geology, The University of Texas at Austin; 1986.

Manrique JF, Kaneko T. Reservoir management strategies for development of gas dissolved in water (brine) reservoirs. In: Presented at the SPE Asia Pacific conference on integrated modelling for asset management, Society of Petroleum Engineers, Yokohama; 2000. doi:10.2118/59420-MS.

Martin JC. A study of simultaneous production of water and gas from aquifers containing initial immobile free gas. In: Presented at the SPE annual technical conference and exhibition, Society of Petroleum Engineers, Las Vegas; 1979. doi:10.2118/8356-MS.

Matthews CS. Possibilities of enhancing gas production from geopressured aquifers. Soc Pet Eng J. 1981;SPE-9733.

MIT. The future of geothermal energy: impact of enhanced geothermal systems (EGS) on the United States in the 21st century (An assessment by MIT-led interdisciplinary panel). Cambridge: Massachusetts Institute of Technology; 2006.

Péneloux A, Rauzy E, Fréze R. A consistent correction for Redlich-Kwong-Soave volumes. Fluid Phase Equilib. 1982;8:7-23. doi:10.1016/0378-3812(82)80002-2. 
Peng D-Y, Robinson DB. A new two-constant equation of state. Ind Eng Chem Fundam. 1976;15:59-64. doi:10.1021/ i160057a011.

Plaksina T, White C. Modeling coupled convection and carbon dioxide injection for improved heat harvesting in geopressured geothermal reservoirs. Geotherm Energy. 2016;4:2. doi:10.1186/s40517-016-0044-x.

Riney TD. Pleasant Bayou geopressured-geothermal reservoir analysis-October 1991. J Energy Resour Technol. 1992;114:315-22. doi:10.1115/1.2905959.

Riney TD. Gladys McCall geopressured reservoir analysis—June 1987. J Energy Resour Technol. 1988;110:262-8. doi:10.1115/1.3231391.

Salimi H, Wolf K-H. Integration of heat-energy recovery and carbon sequestration. Int J Greenh Gas Control. 2012;6:56-68. doi:10.1016/j.ijggc.2011.11.010.

Swanson RK, Bernard WJ, Osoba JS. A summary of the geothermal and methane production potential of US Gulf Coast geopressured zones from test well data. J Pet Technol. 1986;38:1365-70. doi:10.2118/13090-PA.

Wallace RH, Kraemer TF, Taylor RE, Wesselman JB. Assessment of geopressured-geothermal resources in the northern Gulf of Mexico basin. US Geol Surv Circ. 1979;790:132-55.

Wrighton F, Bebout DG, Bachman AL. Economic overview of geopressured solution gas. In: Presented at the fifth geopressured geothermal energy conference, Louisiana State Univ., Baton Rouge; 1981.

Zhang L, Ezekiel J, Li D, Pei J, Ren S. Potential assessment of $\mathrm{CO}_{2}$ injection for heat mining and geological storage in geothermal reservoirs of China. Appl Energy. 2014;122:237-46. doi:10.1016/j.apenergy.2014.02.027.

\section{Submit your manuscript to a SpringerOpen ${ }^{\circ}$ journal and benefit from:}

- Convenient online submission

\section{- Rigorous peer review}

- Immediate publication on acceptance

- Open access: articles freely available online

- High visibility within the field

Retaining the copyright to your article

Submit your next manuscript at $\gg$ springeropen.com 